\title{
Med tvivlen som følgesvend: En analyse af omfang af og kilder til studietvivl blandt studerende
}

\author{
Kim J. Herrmann, ph.d., adjunkt, Center for Undervisning og Læring, AU \\ Rie Troelsen, ph.d., lektor, Institut for Kulturvidenskaber, SDU \\ Anna Bager-Elsborg, ph.d.-stipendiat, Center for Undervisning og Læring, AU \\ Reviewet artikel
}

De senere års uddannelsespolitiske initiativer har belønnet studerende, der er hurtige til at vælge en videregående uddannelse, og som holder fast i den uddannelse, de nu engang har valgt. At vælge uddannelse er imidlertid ledsaget af tvivl, og nyere dansk forskning har vist, at studerende vedvarende forhandler deres position på uddannelsen. I dette studie undersøgte vi, hvor stor en andel af aktive universitetsstuderende, der stadig var i tvivl om deres valg af studie, og vi undersøgte baggrunden for denne tvivl. På baggrund af en kvantitativ analyse af svar fra 4.339 studerende på Aarhus School of Business and Social Sciences, Aarhus Universitet, fandt vi, at en tredjedel af de studerende, selv efter optagelse på deres uddannelse, stadig var i tvivl om, hvorvidt de havde valgt det rigtige studie, og at dette gjaldt for førsteårsstuderende såvel som for studerende på femte år. Analysen viste yderligere, at studietvivl var mere udbredt blandt studerende, som havde (i) svært ved at se det interessante og relevante i fagene; (ii) lav tiltro til egne akademisk evner; (iii) opnået lave karakterer ved forudgående eksamener på universitetet. I artiklens perspektivering diskuterer vi, hvorvidt studietvivl må betragtes som et almindeligt og uproblematisk studieog livsvilkår eller, om studietvivl må antages at være problematisk.

\section{Introduktion}

De seneste 10 års politiske reformer på uddannelsesområdet har været til gavn for den sikre og målrettede studerende. En studerende, som tidligt sporer sig ind på sit fag, en studerende som målrettet planlægger og gennemfører sit studie, en studerende, hvis uddannelse har klar erhvervsrettet relevans. Vi vil med denne artikel imidlertid gerne give plads til også at belyse tvivlen, som synes at være et grundvilkår for en betragtelig del af de universitetsstuderende.

I forbindelse med undervisningsmiljøvurderingen på Aarhus School of Business and Social Sciences, Aarhus Universitet, spurgte vi de studerende om, hvorvidt de var i 
tvivl om deres valg af nuværende studie, og det er dette spørgsmål vi gerne vil analysere nærmere ved hjælp af de data, som vi havde til rådighed for undersøgelsen i øvrigt. Man kan indvende, at det næppe er overraskende, at studerende er i tvivl om deres studievalg, også efter påbegyndt uddannelse. En sådan indvending er dog efter vores vurdering ikke et argument for at undlade at interessere sig for studietvivl. For det første, fordi valg af studie knytter sig til de to områder af livet, som individer oftest fortryder, nemlig uddannelsesvej og karrierebane, hvorved valg af studie har en signifikant betydning for den enkeltes liv (Roese \& Summerville, 2005). For det andet, fordi studietvivl er forbundet med de studerendes faglige identitet og oplevelse af meningsfuldhed (Herrmann, Bager-Elsborg \& McCune, upubliceret), hvilket igen kan få konsekvenser for dybden af de studerendes engagement (McCune, 2009).

\section{Artiklens mål}

På baggrund af undervisningsmiljøundersøgelsen ved Aarhus School of Business and Social Sciences ønskede vi, for det første, at foretage en analyse af, hvor stor en andel af de studerende, der udtrykte studietvivl. For det andet ønskede vi at undersøge, hvordan de studerendes oplevelse af læringsmiljøet hang sammen med følelsen af studietvivl.

I denne artikel redegøres der først for de væsentligste uddannelsespolitiske reformer samt for forskningslitteratur, der kan belyse begrebet studietvivl. Dernæst analyseres, hvor stor en del af de studerende, der oplever studietvivl, og hvordan studietvivl hænger sammen med de studerendes oplevelse af læringsmiljøet. Resultaterne diskuteres i forhold til lignende resultater fra frafaldsforskningen, og herunder diskuterer vi, hvornår studietvivl kan antages at være konstruktiv, og hvornår den må antages at være hæmmende. Afslutningsvis perspektiveres resultaterne til den uddannelsespolitiske diskurs.

\section{Nyere uddannelsespolitiske reformer}

Siden 2003 er der vedtaget tre større uddannelsesreformer, som belønner målrettede og effektive studerende og gør det omkostningsfuld at vælge om eller blive forsinket. Reformerne udtrykker et fokus på (og en forventning om) at studerende går "den lige vej" igennem uddannelsessystemet, og reformerne udtrykker helt eksplicit, at studieomvalg eller -frafald udgør et problem for både individ og samfund (Undervisningsministeriet, 2003). Med gymnasiereformen indførte et flertal i Folketinget i 2003 en specialisering med studieretninger, hvor gymnasieeleverne tidligt skal vælge sig ind på et fagligt spor. Der blev i 2009 også indført en karakterbonus, hvilket betød, at studerende, der søgte optagelse på en bacheloruddannelse inden to år, kunne gange deres karaktergennemsnit med 1,08 (Undervisningsministeriet, 2009). I 2013 blev Studiefremdriftsreformen vedtaget med virkning fra 2016. En del af denne reform angik SU-systemet og indebærer, at studerende ophører med at modtage SU efter 6 måneders studieinaktivitet (mod 12 måneder i dag). Antallet af SU-klip reduceres, så det alene svarer til normeret studietid, og studerende, der færdiggør deres uddannelse hurtigere end på normeret studietid, modtager en økonomisk bonus (Styrelsen for Videregående Uddannelser, 2013). Et andet aspekt af reformen er, at 
universiteterne er forpligtet til at sikre større fleksibilitet mellem uddannelser, og til at sikre, at studerende læser på fuld tid ved at studerende skal tilmeldes fag og eksamener svarende til 60 ECTS-point pr. år. Reformen betyder, at universiteterne kan imødese en reduktion i tildeling af midler, hvis de ikke lykkes med at få studerende hurtigere igennem studierne (Uddannelses- og Forskningsministeriet, 2013).

\section{Arsager til studiefravalg}

Der er os bekendt ikke en klar begrebsmæssig definition eller forståelse af, hvad studietvivl er. Til gengæld findes der en omfattende litteratur om universitetsstuderendes studiefrafald, der kan bidrage til forståelsen af tvivl. Frafald bliver som regel defineret som et om- eller fravalg af studium (Tinto, 1993), og årsagerne til det endelige om- eller fravalg kan meget vel tænkes at være tæt relateret til årsagerne til, at den studerende kommer i tvivl om, om valget af studium nu har været det rigtige fra starten. Data fra Aarhus Universitet (2014) viste, at studietvivl var mere udbredt blandt studerende, der havde afbrudt deres studier ved Aarhus School of Business and Social Sciences, men samtidig viste analysen, at studietvivl også var udbredt blandt studerende, der stadig var aktive. At være i tvivl om valget af sit studium er derfor ikke det samme som at droppe ud af sit studium, men forskning inden for frafald kan måske pege på områder, som også kan have betydning for studietvivl.

Inden for frafaldsforskningen peges der på to slags faktorer som årsag til frafaldet: faktorer forud for studiet og faktorer under studiet. Blandt faktorer forud for studiet er den studerendes køn og socio-demografiske baggrund, herunder særligt forældrenes uddannelsesmæssige baggrund. Børn af forældre uden akademisk uddannelse har større frafaldssandsynlighed, ligesom mænd oftere falder fra end kvinder (Larsen et al., 2013). Angående faktorerne under studiet er det ikke helt så entydigt, hvad der er årsag til frafald. En del undersøgelser peger på manglen på akademisk integration som en årsag, dvs. de studerende oplever de faglige udfordringer som enten for høje eller for lave (Hovdhaugen \& Aamodt, 2009; Loyens, Rikers \& Schmidt, 2007). Færre undersøgelser peger på manglende social integration som årsag, dvs. utilfredshed med studiemiljø og/eller undervisningsformer (Kolland, 2002). Også manglende motivation og dalende interesse nævnes som årsag til frafald (Van Bragt, Bakx, Bergen \& Croon, 2011; Yorke \& Longden, 2008).

Men selv om frafald versus ikke-frafald udgør en dikotomi, viser andre dele af frafaldsforskningen, at der snarere bør tales om en gradvis proces, hvor fravalget typisk sker, når studium og studerende ikke lever op til hinandens forventninger i tilstrækkelig grad. Ulriksen, Madsen og Holmegaard (2014) beskriver dette som kløften mellem forventning og realitet. Via en interviewundersøgelse af 20 førsteårsstuderende ved en række naturvidenskabelige uddannelser, peger forskerne på, at de studerende oplever deres første år på studiet som bl.a. forhandlings- og rekonstruktionsprocesser, hvor de studerende hele tiden afvejer forskellige studieelementer i bestræbelserne på at få deres forventninger til at modsvare realiteterne. De studerende i undersøgelsen havde alle valgt studiet, fordi de var interesserede i faget, men nogle af dem faldt fra igen, fordi studiet - og alt hvad det indebar - ikke levede op til deres 
oprindelige forventninger. Oversat til studietvivl kan man sige, at disse studerende faldt fra, fordi tvivlen blev dem for meget - at tvivlen på, at forventninger og realiteter nogensinde ville mødes, blev for stor.

\section{Metode}

\section{Deltagere}

I denne undersøgelse var deltagerne studerende ved Aarhus School of Business and Social Sciences ved Aarhus Universitet. Fakultetet dækker syv institutter, som udbyder bachelor- og kandidatuddannelser inden for de økonomiske og sociale videnskaber (fx Økonomi, Erhvervsøkonomi, Erhvervskommunikation, Psykologi, Jura og Statskundskab). I alt svarede 4.339 studerende på spørgeskemaet udsendt i foråret 2014 i forbindelse med undersøgelsen af studiemiljøet ved Aarhus Universitet. Dette svarer til 34\% af de adspurgte. De studerendes gennemsnitsalder var 24 år (std.afv. 3,8). $61 \%$ var bachelorstuderende, mens de resterende $39 \%$ var kandidatstuderende.

\section{Dataindsamling}

Data udgøres af en kombination af studieadministrative data og de studerendes svar på et spørgeskema. Spørgeskemaet dækkede en bred undersøgelse af de studerendes psykiske studiemiljø. I nærværende undersøgelse, analyserer vi en delmængde af disse spørgsmål (se appendiks for en oversigt over centrale variable). De studerendes oplevelse af læringsmiljøet blev målt ved hjælp af en modificeret udgave af Enhancing Teaching and Learning Questionnaire (Entwistle, McCune \& Hounsell, 2003; Parpala \& Lindblom-Ylänne, 2012), som rummer seks refleksive skalaer til måling af de studerendes oplevelse af læringsmiljøet: (i) 'interesse og relevans', (ii) 'konstruktiv feedback', (iii) 'støtte og entusiasme fra undervisere', (iv) 'støtte fra medstuderende', (v) 'alignment i undervisningen', samt (vi) 'vægt på forståelse'. Den danske oversættelse af disse skalaer blev valideret i Herrmann, Bager-Elsborg \& Parpala, upubliceret). Endelig inkluderede vi skalaen (vii) 'tiltro til egne faglige evner' (Parpala \& Lindblom-Ylänne, 2012), som er udviklet på baggrund af skalaen 'self-efficacy beliefs' (Pintrich et al., 1990). Ud over spørgeskemaet indhentede vi oplysninger om de studerendes køn, alder, studietrin og karaktergennemsnit på universitetet.

Studietvivl blev målt ved hjælp af ét spørgsmål, nemlig: "Nogle gange kan jeg godt tvivle på, om det var det rigtige valg at læse det her fag". Dette spørgsmål blev besvaret på en Likert-skala gående fra 'helt uenig' til 'helt enig'. Når vi tolker de studerendes svar på dette spørgsmål, er det vigtigt at være opmærksom på rammesætningen af undersøgelsen. De studerende blev i spørgeskemaet mødt af beskeden: "Vi har fået oplyst, at din primære indskrivning er [uddannelsen som oplyst af studieadministrationen]. Det er dette studie, du skal have i tankerne, når du besvarer skemaet [forfatternes fremhævelse]. Det gælder også, selvom du tager eller har taget sideeller suppleringsfag andre steder, eller hvis dit fag har en specialisering." Når de studerende således udtrykker tvivl om rigtigheden af at læse "det her fag", så skal dette tolkes bredere end et specifikt modul eller valgfag, nemlig som studiet som hovedfag eller hoveduddannelse. 


\section{Statistiske analyser}

Studietvivl blev målt som en ordinal skaleret variabel, men da forudsætningen for at foretage ordinal logistisk regression ikke var opfyldt, valgte vi at anvende binær logistisk regression på en dikotomiseret udgave af variablen (Orme \& Combs-Orme, 2009). Svarene 'helt enig' og 'overvejende enig' til udsagnet "Nogle gange kan jeg godt tvivle på om det var det rigtige valg at læse det her fag" blev kategoriseret som tvivl. Svarene, 'overvejende uenig' og 'helt uenig' blev kategoriseret som ikke-tvivl. Også midter-svaret 'hverken enig eller uenig' blev kategoriseret som ikke-tvivl.

\section{Resultater}

\section{Omfang af tvivl}

I den første del af analysen undersøgte vi, hvor stor en andel af de studerende, der udtrykte studietvivl ved at svare bekræftende på udsagnet "Nogle gange kan jeg godt tvivle på, om det var det rigtige valg at læse det her fag". Som det ses af figur 1 svarede $11 \%$ 'helt enig' og $24 \%$ 'overvejende enig' til udsagnet. Med andre ord viste det sig, at 35\% af de adspurgte studerende bekræftede, at de nogle gange tvivlede på, at det var det rigtige valg at læse faget. Andelen af adspurgte studerende, der udtrykte studietvivl, var nogenlunde konstant på tværs af studietrin, hvilket vil sige, at de adspurgte studerende i s/utningen af deres universitetsuddannelse var lige så meget i tvivl om rigtigheden af deres studievalg som studerende i begyndelsen af deres universitetsuddannelse. En simpel bivariat analyse af sammenhængen mellem studietrin og studietvivl viste, at der var en statistisk signifikant men substantielt set triviel forskel mellem studietrinene $\left(r_{\square}=-0,052 ; p<0,001\right)$.

Figur 1. Frekvensanalyse for svar til udsagnet "Nogle gange kan jeg godt tvivle på om det var det rigtige valg at læse det her fag." fordelt på studietrin.

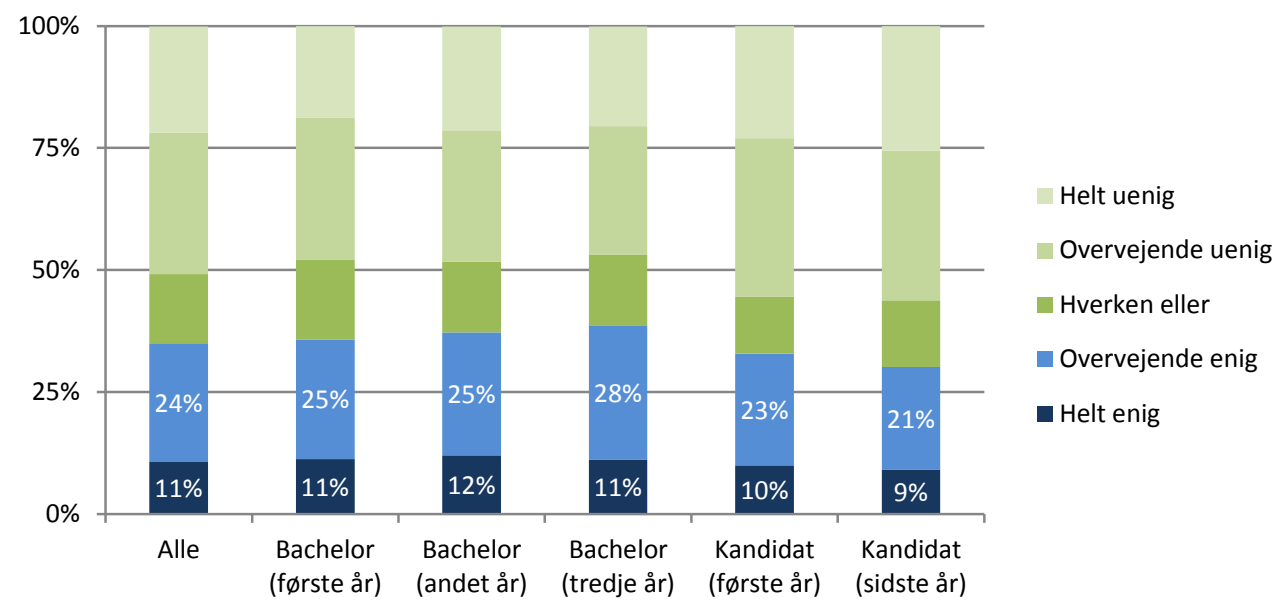

$\mathrm{N}($ alle $)=4.322$

\section{Studietvivl og opfattelse af læringsmiljøet}

I den anden del af analysen undersøgte vi, i hvilket omfang studietvivl korrelerede med variable, som relaterede sig til de studerendes oplevelse af læringsmiljøet, deres tillid til egne faglige evner samt en række baggrundsvariable (se appendikset for en nærmere beskrivelse af de inkluderede variable). 
Tabel 1. Parameterestimater for binær logistisk regression med studietvivl som funktion af de studerendes oplevelse af læringsmiljøet, studerendes tiltro til egne faglige evner samt studerendes baggrundskarakteristika.

\begin{tabular}{|c|c|c|c|}
\hline & Logit & (standardfejl) & Odds-ratio \\
\hline (konstant) & 5,097 & & \\
\hline \multicolumn{4}{|l|}{ Oplevelse af læringsmiljøet } \\
\hline Interesse og relevans ${ }^{a}$ & $-0,856 * \star \star$ & $(0,070)$ & 0,425 \\
\hline Konstruktiv feedback $^{\mathrm{a}}$ & 0,000 (n.s.) & $(0,050)$ & 1,000 \\
\hline $\begin{array}{l}\text { Støtte og entusiasme fra undervise- } \\
\text { re }^{a}\end{array}$ & 0,062 (n.s.) & $(0,067)$ & 1,064 \\
\hline Støtte fra medstuderende ${ }^{a}$ & 0,109 (n.s.) & $(0,061)$ & 1,115 \\
\hline Alignment i undervisningen ${ }^{a}$ & $-0,039$ (n.s.) & $(0,064)$ & 0,962 \\
\hline Vægt på forståelse ${ }^{a}$ & $-0,004$ (n.s.) & $(0,054)$ & 0,996 \\
\hline \multicolumn{4}{|l|}{ Selvtillid } \\
\hline Tiltro til egne faglige evner ${ }^{a}$ & $-0,495^{* * *}$ & $(0,060)$ & 0,609 \\
\hline \multicolumn{4}{|l|}{ Baggrundsvariable } \\
\hline Alder (antal år) & $-0,019$ (n.s.) & $(0,012)$ & 0,981 \\
\hline \multicolumn{4}{|l|}{ Køn } \\
\hline Mand & (reference) & & \\
\hline Kvinde & $0,169 *$ & $(0,071)$ & 1,184 \\
\hline \multicolumn{4}{|l|}{ Studietrin } \\
\hline Første år (bach.) & (reference) & & \\
\hline Andet år (bach.) & 0,058 (n.s.) & $(0,111)$ & 1,060 \\
\hline Tredje år (bach.) & 0,205 (n.s.) & $(0,109)$ & 1,228 \\
\hline Fjerde år (kand.) & 0,018 (n.s.) & $(0,124)$ & 1,018 \\
\hline Femte år (kand.) & 0,034 (n.s.) & $(0,129)$ & 1,035 \\
\hline Karakter-gns. & $-0,081 * * *$ & $(0,019)$ & 0,922 \\
\hline N & 4.234 & & \\
\hline Cox \& Snell $\mathrm{R}^{2}$ & 0,106 & & \\
\hline Nagelkerke $\mathrm{R}^{2}$ & 0,146 & & \\
\hline
\end{tabular}

Note: Afhængig variabel: “Nogle gange kan jeg godt tvivle på om det var det rigtige valg at læse det her fag." 0 = 'helt uenig', 'overvejende uenig' eller 'hverken enig eller uenig', 1 = 'overvejende enig' eller 'helt enig'.

Note: * $p<0,050$, ** $p<0,010$, *** $p<0,001$, (n.s.) ikke statistisk signifikant på femprocentsniveau. a) Refleksive skalaer fra 1 (lav) til 5 (høj), se tabel i appendiks for nærmere beskrivelse. 
Af tabel 1 kan man se, at der var en negativ og statistisk signifikant sammenhæng mellem henholdsvis studietvivl og de studerendes oplevelse af, at fagene på studiet var interessante og relevante. En odds-ratio på 0,425 kan fortolkes på følgende måde: En forøgelse af scoren på 1 på skalaen 'interesse og relevans' mindsker oddsene for at tvivle med en faktor $2,4\left[=(0,425)^{-1}\right]$. En anden tolkning er, at en forøgelse af scoren med 1 på skalaen 'interesse og relevans' mindsker oddsene for at tvivle med $140 \%\left[=100\left(0,425^{-1}-1\right)\right]$. Sagt med andre ord, jo mere de adspurgte studerende oplevede fagene på studiet som interessante og relevante, desto mindre tilbøjelighed til at tvivle om valg af studie.

På samme måde viste modellen en negativ sammenhæng mellem studietvivl og studerendes tiltro til egne faglige evner. Til gengæld syntes der ikke at være statistisk signifikante sammenhæng mellem henholdsvis studietvivl og oplevelse af feedback, støtte fra medstuderende, alignment, vægt på forståelse, og undervisernes entusiasme.

Der kunne også observeres statistiske signifikante effekter af både køn og faglig succes (udtrykt ved de studerendes gennemsnit af karakterer ved karakterbedømte eksamener ved universitetet). Kvinders odds for at opleve studietvivl var $18 \%$ $[100(1,184-1)]$ højere sammenlignet med mændenes. Endelig mindskedes oddsene for studietvivl med $8 \%\left[100\left(0,922^{-1}-1\right)\right]$ for hver gang, de studerendes gennemsnitskarakter øgedes med ét point. Til gengæld syntes der ikke at være statistisk eller substantielt signifikante forskelle mellem studerende i begyndelsen, midten, eller sidst i deres uddannelse.

Odds og odds-ratioer er ikke intuitive at fortolke. Derfor udregnede vi sandsynlighederne for studietvivl som funktion af scorer på udvalgte variable og illustrerede dette grafisk i de to nedenstående figurer. 
Figur 2. Estimeret sandsynlighed for studietvivl som funktion af hhv. de studerendes oplevelse af fagene som interessante og relevante (blå linje) og de studerendes tiltro til egne faglige evner (grøn linje).

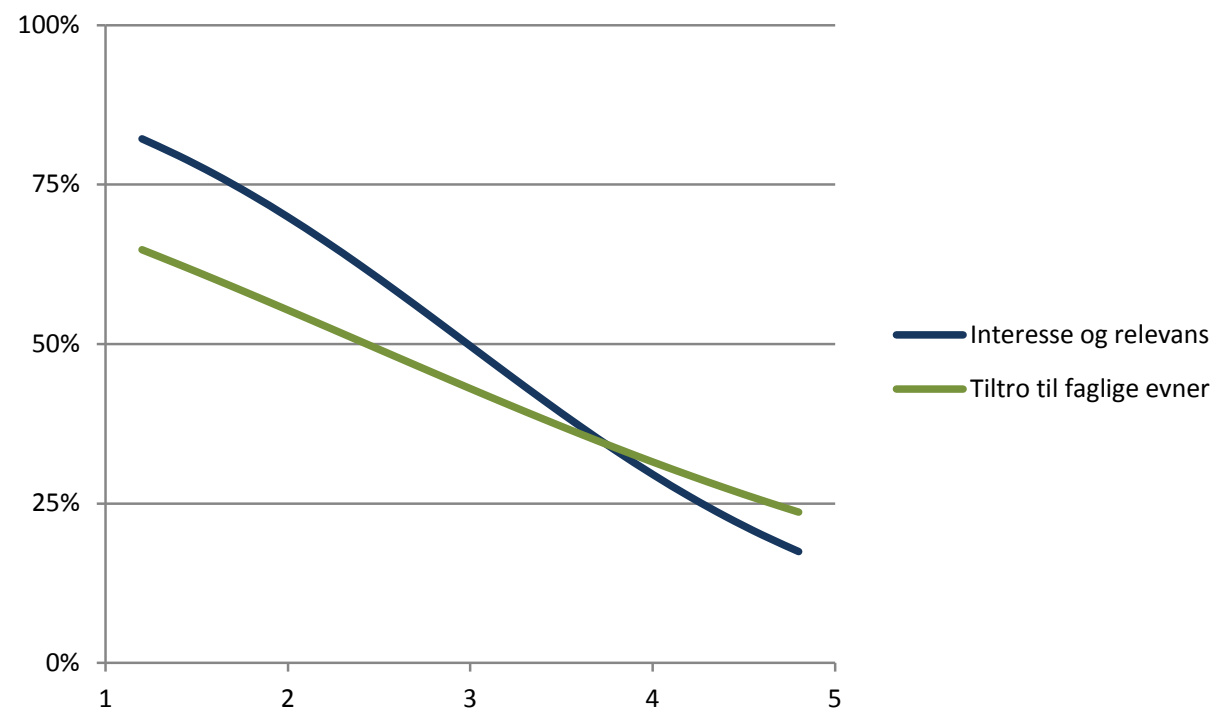

Graferne er beregnet på baggrund af den logistiske model præsenteret i tabel 2. Referencekategorien er en 24-årig mandlig førsteårsstuderende med et karaktergennemsnit på 7,2. Alle øvrige refleksive skalaer er holdt på gennemsnittet for samplet.

Y-aksen: Den estimerede sandsynlighed for at erklære sig overvejende eller helt enig i udsagnet: "Nogle gange kan jeg godt tvivle på om det var det rigtige valg at læse det her fag."

X-aksen: Score på den refleksive skala fra 1 (lille, lav) til 5 (stor, høj).

Figur 2 viser, hvordan sandsynligheden for at føle studietvivl falder markant med høje scorer på skalaen 'interesse og relevans'. Jo mere den studerende opfatter faget som relevant og interessant desto mindre er sandsynligheden for, at den studerende føler tvivl om valget af sit fag. På samme måde viser figur 2, at sandsynligheden for studietvivl falder markant, om end mindre, med høj score på skalaen 'tiltro til egne faglige evner'. Sagt på en anden måde, jo mere den studerende er usikker på, hvorvidt han eller hun har de fornødne evner til at klare sig godt fagligt, desto større er sandsynligheden, ifølge modellen, for at føle tvivl om valget af fag.

Figur 3 viser på lignende måde en negativ sammenhæng mellem studietvivl og gennemsnittet af resultater ved karakterbedømte eksamener. Jo bedre den studerende klarede sig fagligt, desto mindre sandsynligheden for studietvivl. 
Figur 3. Sandsynlighed for studietvivl som funktion resultater ved karakterbedømte eksamener.

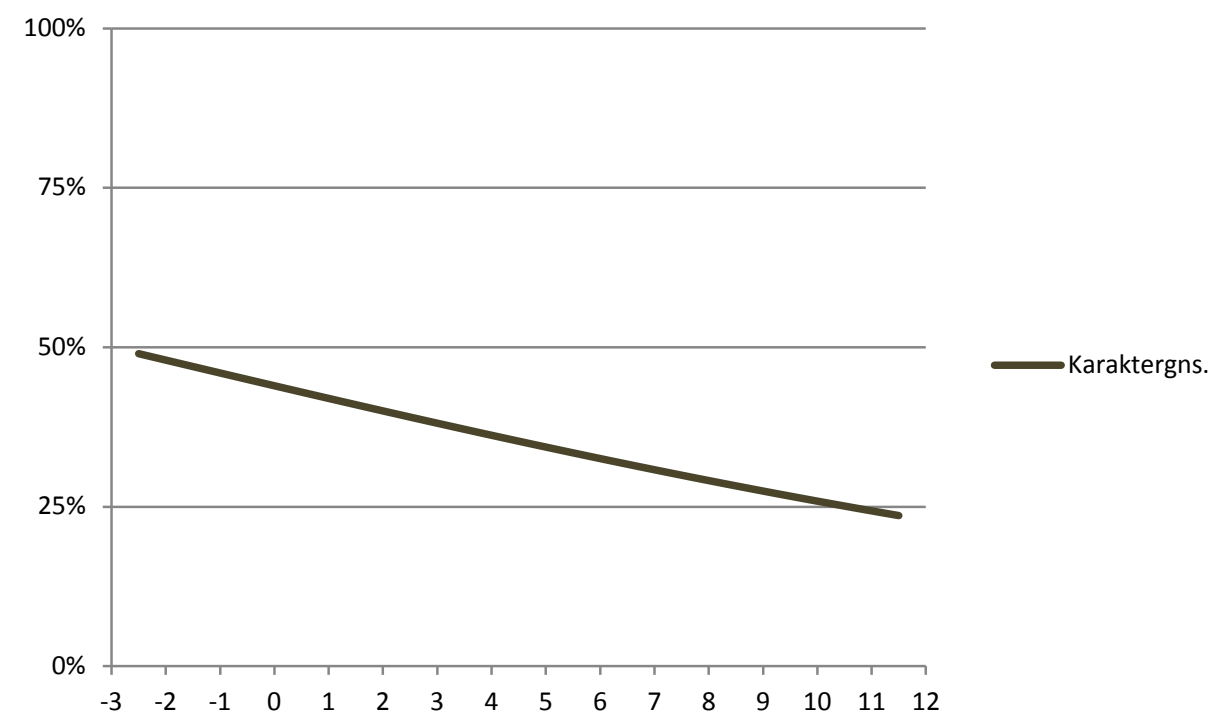

Grafen er beregnet på baggrund af den logistiske model præsenteret i tabel 2. Referencekategorien er en 24-årig mandlig førsteårsstuderende. Alle øvrige refleksive skalaer er holdt på gennemsnittet for samplet.

Y-aksen: Sandsynligheden for at erklære sig overvejende eller helt enig i udsagnet: "Nogle gange kan jeg godt tvivle på om det var det rigtige valg at læse det her fag." X-aksen: Gennemsnittet for karakterbedømte eksamener på uddannelsen.

\section{Diskussion}

\section{Undersøgelsens hovedresultater}

Analysen viste for det første, at det var meget normalt for en betydelig andel af de adspurgte studerende sommetider at tvivle på, om de nu havde valgt det rigtige studie. En tredjedel af de studerende kunne erklære sig enige i udsagnet "Nogle gange kan jeg godt tvivle på om det var det rigtige valg at læse det her fag", og oplevelsen af at tvivle var lige udbredt blandt førsteårs bachelorstuderende og kandidatstuderende på deres sidste år. For det andet viste analysen, at sandsynligheden for, at den studerende svarede bekræftende på udsagnet "nogle gange kan jeg godt tvivle på om det var det rigtige valg at læse det her fag", øgedes i takt med, at den studerende vurderede spørgsmålene om interesse og relevans lavere, og i takt med at de vurderede spørgsmålet om tiltro til egne faglige evner lavere. Dertil var der en signifikant sammenhæng mellem oplevelsen af at være i tvivl og karaktergennemsnit. Jo højere karaktergennemsnit i karakterbedømte eksamener på universitetet, desto sjældnere svarede studerende, at de nogle gange var i tvivl om deres valg af fag.

Den negative sammenhæng mellem studietvivl og henholdsvis tillid til egen faglige formåen og karaktergennemsnit peger på, at årsagerne til den oplevede tvivl i mange tilfælde er de samme som årsagerne til frafald, hvor de studerendes oplevelse af ikke at kunne honorere de faglige krav også spiller ind (Hovdhaugen \& Aamodt, 2009). På samme måde korresponderer resultaterne fra denne undersøgelse med resultater fra frafaldsforskningen, hvor nogle studier viser, at årsager til frafald knyt- 
ter sig til fravær af motivation i form af manglende interesse (Van Bragt, Bakx, Bergen \& Croon, 2011). Resultaterne peger desuden på, at kvinder i højere grad end mænd oplever nogle gange at være i tvivl om valget af deres fag. Da litteraturen viser, at mænd har øget tilbøjelighed til frafald (Larsen et al., 2013), og denne undersøgelse er foretaget syv måneder inde i studieåret, kan man overveje, om mænd med stor tvivl allerede på dette tidspunkt er faldet fra, mens at de tvivlende kvinder stadig holder fast i deres studievalg.

\section{Konstruktiv og ikke-konstruktiv studietvivl}

Tvivlen er altså en følgesvend for mange studerende op gennem deres uddannelsesforløb, men reaktionen på tvivlen er forskellig. Nogle fravælger studiet og andre bliver, og hverken frafald eller studietvivl bør nødvendigvis elimineres. Hvad angår frafald, kan man tale om det hensigtsmæssige/uhensigtsmæssige frafald, idet frafaldet kan ske af 'rigtige' grunde ( $f x$ at studiets mål og den studerendes evner ikke matcher hinanden eller at den studerende er indskrevet på to uddannelser og må vælge én fra) eller 'forkerte' grunde ( $f x$ at den studerende har taget sin beslutning om fravalget på baggrund af kun få ugers undervisning eller, at den studerende farer vild i administrative procedurer).

På samme måde kan man tale om en konstruktiv/ikke-konstruktiv tvivl. Den konstruktive tvivl er den tvivl, der får studerende til at foretage informerede til- og fravalg. Faktisk viste en undersøgelse fra Norge, at studietvivl baseret på følelsen af ikke at være motiveret, eller at studiet ikke svarede til forventningerne, i højere grad var relateret til omvalg og ikke fravalg, dvs. at de studerende blot valgte et andet studium og altså ikke faldt helt ud af uddannelsessystemet (Hovdhaugen, 2009).

Den ikke-konstruktive studietvivl er derimod den tvivl, som forhindrer den studerende i fuldt og helt at engagere sig i sit studie. En nylig analyse har vist, at spørgsmålet om studietvivl (sådan som det er formuleret i netop denne undersøgelse) sammen med spørgsmålene "Studiet har bidraget til, at jeg føler mig som en del af et fagligt fællesskab", "Jeg glæder mig til at komme ud og arbejde med mit fag", og "Mit fag er en vigtig del af min identitet" synes at måle studerendes faglige identitet (Herrmann, Bager-Elsborg \& McCune, upubliceret). Studietvivl synes således at være knyttet til faglig identitetsdannelse, hvilket stemmer overens med anden forskning på området. Fx viste et studie af McCune (2009) af biologistuderende på kandidatniveau, at de dybt engagerede studerende oplevede undervisningen og dens indhold som værdifuld og meningsfuld, ligesom de udtrykte større tillid til deres faglige formåen. De studerende i McCunes undersøgelse kædede deres oplevelse af engagement i undervisningen sammen med en opfattelse af sig selv som 'videnskabsfolk', hvilket tyder på, at engagement er tæt knyttet til faglig identitet.

\section{Curriculum}

Resultaterne giver anledning til at overveje, hvordan uddannelsesinstitutionerne kan understøtte den hensigtsmæssige tvivl gennem strukturering og indholdsgivning af uddannelserne. Resultaterne peger på, at feedback, alignment i undervisningen og 
støtte fra medstuderende i de studerendes optik ikke har betydning for, om de oplever nogle gange at tvivle på deres valg. Derimod har manglende tiltro til egen faglig formåen betydning for deres oplevelse af at komme i tvivl. Man kan tolke dette som om de studerende tager det på sig, at de er kommet i tvivl - de mener, at studiet og undervisningen er, som det skal være, men at det nok er dem og deres faglige formåen, der ikke passer ind. Det vil i så fald ligne andre studier af årsager til frafald, hvor de studerende ligeledes tildeler sig selv ansvaret for den manglende tilpasning (Holm, Laursen \& Winsløw, 2008).

Som med frafald er studietvivl ikke alene de studerendes ansvar. Institutionerne har et medansvar og kan i højere grad sigte mod at skabe en faglig identitet for de studerende tidligt i uddannelsesforløbet. Curriculum kan designes, så tvivlen italesættes som en naturlig og hensigtsmæssig del af livet som universitetsstuderende. Målet er at minimere kløften imellem studerendes forventninger til studiet og realiteterne, som de oplever dem. En kløft, som potentielt fører til frafald (Ulriksen, Madsen, \& Holmegaard, 2014). Uddannelsesinstitutionerne har ikke råd til, at studerende trækker studietiden for at håndtere tvivlen, men må i stedet give tvivlen plads og rum som en del af studiet. Og det skal ikke kun være som en del af et introduktionsforløb. For selvom Ulriksen og kolleger har de studerendes forhandlings- og rekonstruktionsprocesser i løbet af første år som omdrejningspunkt, så viser vores analyser, at selv studerende i slutningen af deres studium udtrykker studietvivl, og at de indre forhandlingsprocesser derfor sandsynligvis foregår gennem hele studiet.

\section{Undersøgelsens styrker og svagheder}

Tvivl er i denne undersøgelse kædet sammen med beslutninger omkring at fortsætte eller afbryde et uddannelsesforløb. Vi har argumenteret for, at tvivl er en følgesvend for de studerende, men ikke desto mindre opfattes tvivl som et problem i uddannelsessammenhæng, fordi det forhindrer studerende i at gennemføre uddannelsen hurtigt. Tvivl er dog ligeledes et væsentligt akademisk redskab, som studerende gennem en universitetsuddannelse skal lære at mestre. Det er imidlertid ikke denne akademiske tvivl artiklen behandler eller, som spørgsmålet i undersøgelsen har søgt at afdække. Vi kan dog ikke være sikre på, hvilken tvivl de studerende har haft i tankerne, da de besvarede spørgsmålet. En mulig løsning er en ny operationalisering af tvivl, fx ved at udvikle en refleksiv skala med flere spørgsmål som mere nuanceret afdækker begrebet.

Nogle af de væsentligste styrker ved designet er til gengæld, at der i undersøgelsen indgår et stort antal studerende fra et bredt udvalg af uddannelser dækkende både såkaldt bløde (fx Erhvervskommunikation) og hårde fag (fx Økonomi), professionsrettede uddannelser ( $f x$ Jura) og generalistuddannelser ( $f x$ Statskundskab). Dog skal det bemærkes, at generalisering ud over samfundsvidenskabelige uddannelser må foretages med varsomhed, idet et studie af Kucel og Vilalta-Bufí (2013) har vist, at studiefortrydelse blandt færdige kandidater varierer på tværs af de store fagområder. En anden styrke er, at der ved måling af opfattelser af studiemiljøet samt tillid til 
egen faglige formåen er brugt teoretisk baserede og empirisk testede internationale spørgeskemabatterier, hvilket højner målenes validitet.

\section{Konklusion og bredere perspektiver}

I dette studie fandt vi, at studietvivl var udbredt blandt et væsentligt mindretal af aktive studerende på Aarhus School of Business and Social Sciences, Aarhus Universitet, og vi fandt, at tvivlen var relateret til en manglende oplevelse af studiet som interessant og relevant, en manglende tiltro til egen faglige formåen samt et lavere karaktergennemsnit. Dette resultat korresponderer med lignende resultater fra frafaldsforskningen, om end studietvivl ikke kan sidestilles med et frafald.

Studietvivl er muligvis et grundvilkår ved at være studerende, lige som tvivl i almindelighed kan siges at være et grundvilkår i tilværelsen. Studietvivl kan muligvis også være positivt i det tilfælde, hvor studerende tager et informeret fravalg eller et aktivt tilvalg af deres studie. Vi vil imidlertid ud fra nyere universitetspædagogisk forskning vove den påstand, at en konstant studietvivl må antages at være kontraproduktiv i forhold til det faglige læringsarbejde i det omfang, studietvivlen er et symptom på manglende integration i et fagligt/akademisk fælleskab.

Netop derfor er der grund til at interessere sig nærmere for fænomenet studietvivl, for i en tid, hvor der i samfundet rettes så stor opmærksomhed mod studerendes mest effektive vej gennem uddannelsessystemet, risikerer man at tabuisere netop tvivlen. Studietvivl er øjensynligt helt normalt forekommende hos en betragtelig del af de universitetsstuderende i denne undersøgelse. Studietvivlen er værd at interessere sig for, da den er vedvarende og har betydning for studerendes faglige identitetsdannelse og læring. Vores personlige betragtning er, at tvivl ikke skal gemmes af vejen, negligeres eller ignoreres, men italesættes og udforskes. Vi håber, at vi med dette studie har bidraget hertil.

Kim J. Herrmann er adjunkt ved Center for Undervisning og Læring, Aarhus Universitet. Han forsker i universitetsstuderendes studiestrategier og oplevelser af undervisningsmiljøet. Sammen med Anna Bager-Elsborg er han ansvarlig for kompetenceudvikling for studenterundervisere og instruktorer ved School of Business and Social Sciences. Han er forfatter til bogen Effektiv holdundervisning - en håndbog for nye undervisere på universitetsniveau ligeledes sammen med Anna Bager-Elsborg.

Rie Troelsen er lektor i universitetspædagogik ved Syddansk Universitet. Her arbejder hun med undervisnings- og uddannelsesudvikling, efteruddannelse og kompetenceudvikling hos universitetsansatte. Hendes forskningsinteresser er bl.a. de unges studievalg - hvilke forventninger har de unge til studiet og omvendt, og hvad er årsagerne til nogle unges studiefravalg?

Anna Bager-Elsborg, ph.d.-stipendiat ved Center for Undervisning og Læring. Hun forsker i faglige fællesskabers og faglige diskursers betydning for universitetsunderviseres tilgange til underviserrollen. Har sammen med Kim J. Herrmann været ansvarlig for studiemiljøundersøgelserne ved Aarhus Universitet i 2007, 2011 og 2014. 


\section{Litteratur}

Aarhus Universitet (2014). Studiemiljøundersøge/se 2014. Aarhus: Aarhus Universitet. Tilgået den 24.4.2015 på www.au.dk/studiemiljo

Entwistle, N. J. (2009). Teaching for Understanding at University: Deep Approaches and Distinctive Ways of Thinking. Basingstoke, UK: Palgrave Macmillan.

Entwistle, N., McCune, V. \& Hounsell, J. (2003). Investigating ways of enhancing university teaching-learning environments: Measuring students' approaches to studying and perceptions of teaching. In E. De Corte, L. Verschaffel, N. Entwistle \&J. van Merriënboer (red.) Powerful Learning Environments: Unravelling Basic Components and Dimensions. Oxford: Elsevier Science.

Herrmann, K. J., Bager-Elsborg, A. \& McCune, V. (upubliceret). Investigating the relationships between approaches to learning, learner identities and students' self-efficacy beliefs.

Herrmann, K. J., Bager-Elsborg, A. \& Parpala, A. (upubliceret). Measuring perceptions of the learning environment and approaches to learning - a validation of a questionnaire.

Holm, C., Laursen, K. B. \& Winsløw, C. (2008). Hvorfor gik de ud? En analyse af frafald på årgang 2006 af matematikstudiet. København: Institut for Naturfagsdidaktik, Københavns Universitet.

Hovdhaugen, E. \& Aamodt, P. O. (2009). Learning environment: Relevant or not to students' decision to leave university? Quality in Higher Education, 15(2), s. 177-789.

Hovdhaugen, E. (2009). Transfer and dropout: different forms of student departure in Norway. Studies in Higher Education, 34(1), s. 1-17.

Kolland, F. (2002). Studienabbruch: Zwischen Kontinuität und Krise. Eine empirische Untersuchung an Österreichs Universitäten. Wien: Braumüller.

Kucel, A. \& Vilalta-Bufí, M. (2013). Why do tertiary education graduates regret their study program? A comparison between Spain and the Netherlands. Higher Education, 65, s. 565-579.

Larsen, M. S., Kornbeck, K. P., Kristensen, R. M., Larsen, M. R. \& Sommersel, H. B. (2013). Dropout Phenomena at Universities: What Is Dropout? Why Does Dropout Occur? What Can Be Done by the Universities to Prevent or Reduce It? A Systematic Review. Clearinghouse research series (Vol. 15). Copenhagen: Danish Clearinghouse for Educational Research, Department of Education, Aarhus University.

Loyens, S. M. M., Rikers, R. M. J. P. \& Schmidt, H. G. (2007). The impact of students' conceptions of constructivist assumptions on academic achievement and dropout. Studies in Higher Education, 32(5), s. 581-602.

McCune, V. (2009). Final year biosciences students' willingness to engage: Teachinglearning environments, authentic learning experiences and identities. Studies in Higher Education, 34(3), s. 347-361.

Orme, J. G. \& Combs-Orme, T. (2009) Multiple Regression with Discrete Dependent Variables. New York: Oxford University Press. 
Parpala, A. \& Lindblom-Ylänne, S. (2012). Using a research instrument for developing quality at the university. Quality in Higher Education, 18(3), s. 313-328.

Pintrich, P. R., Smith, D. A. F., Garcia, T. \& McKeachie, W. J. (1990). A Manual for the Use of the Motivated Strategies for Learning Questionnaire (MSLQ). Ann Arbor: University of Michigan, National Center for Research to Improve Postsecondary Teaching and Learning.

Rienecker, L., Jørgensen, P. S., Dolin, J. \& Ingerslev, G. H. (red.). (2013). Universitetspædagogik. Frederiksberg: Samfundslitteratur.

Roese, N. J. \& Summerville, A. (2005) What we regret most... and why. Personality and Social Psychology Bulletin, 31(9), s. 1273-1285.

Styrelsen for Videregående Uddannelser (2013). SU-reformen er vedtaget. Hentet fra Styrelsen for Videregående Uddannelsers hjemmeside d. 14/04/2015: http://www.su.dk/Nyheder/Sider/su-reformenervedtaget.aspx

Tinto, V. 1993. Leaving College. 2nd ed. Chicago: University of Chicago Press.

Uddannelses- og Forskningsministeriet (2013). Lov om ændring af universitetsloven: LOV nr 898 af 04/07/2013. Hentet d. 14/04/2015 fra Retsinformation: https://www.retsinformation.dk/Forms/R0710.aspx?id=152740

Ulriksen, L. (2014). God undervisning på de videregående uddannelser. En forskningsbaseret brugsbog. Frederiksberg: Frydenlund.

Ulriksen, L., Madsen, L. M. \& Holmegaard, H. T. (2014). The first-year experience: Students' encounter with science and engineering programmes. In E. K. Henriksen, J. Dillon \& J. Ryder (red.), Understanding Student Participation and Choice in Science and Technology Education. Dordrecht: Springer Science+Business Media.

Undervisningsministeriet (2009). Bonusordninger - hvad er hvad? Hentet d. 22/04/2015 fra Undervisningsministeriets hjemmeside: http://www.uvm.dk/Aktuelt/ /UVMDK/Content/News/Udd/Videre/2009/Juli/090709-Bonusordninger-hvad-er-hvad Undervisningsministeriet (2003). Vejledningsreformen - kort fortalt. Hentet d. 22/04/2015 fra Undervisningsministeriets hjemmeside: http://pub.uvm.dk/2003/vejledning/

Van Bragt, C. A. C., Bakx, A. W. E. A., Bergen, T. C. M. \& Croon, M. A. (2011). Why students withdraw or continue their educational careers: A closer look at differences in study approaches and personal reasons. Journal of Vocational Education \& Training, 63(2), s. 217-233.

Yorke, M. \& Longden, B. (2008). The first-year experience of higher education in the UK. Final report. York: The Higher Education Academy. 
Appendiks: Oversigt over variable

Tabel 1. Oversigt over variable i undersøgelsen.

\begin{tabular}{|c|c|c|c|c|c|c|c|c|}
\hline & & $\begin{array}{l}\text { Betegnelse / spørgs- } \\
\text { målseksempel }\end{array}$ & \#spm & $\begin{array}{l}\text { Variati- } \\
\text { ti- } \\
\text { onsbr. }\end{array}$ & Gns. & $\begin{array}{l}\text { Std. } \\
\text { afv. }\end{array}$ & $\begin{array}{l}\text { Skæv } \\
\text {-hed }\end{array}$ & $\alpha$ \\
\hline \multirow[t]{7}{*}{$\begin{array}{l}\text { Refleksive } \\
\text { skalaer }^{a}\end{array}$} & $\begin{array}{l}\text { Interesse } \\
\text { og rele- } \\
\text { vans }\end{array}$ & $\begin{array}{l}\text { "Jeg syntes, at det meste } \\
\text { af det, jeg har lært i } \\
\text { fagene, er meget inte- } \\
\text { ressant." }\end{array}$ & 3 & $1-5$ & 4,0 & 0,64 & $-0,86$ & .722 \\
\hline & $\begin{array}{l}\text { Konstruk- } \\
\text { tiv feed- } \\
\text { back }\end{array}$ & $\begin{array}{l}\text { "Den feedback, jeg får } \\
\text { på mine faglige bidrag i } \\
\text { løbet af semesteret, } \\
\text { forbedrer den måde, jeg } \\
\text { lærer og arbejder på." }\end{array}$ & 4 & $1-5$ & 3,3 & 0,87 & $-0,51$ & .810 \\
\hline & $\begin{array}{l}\text { Støtte og } \\
\text { entusias- } \\
\text { me fra } \\
\text { undervise- } \\
\text { re }\end{array}$ & $\begin{array}{l}\text { "Underviserne forsøger } \\
\text { at dele deres entusias- } \\
\text { me for faget med os." }\end{array}$ & 4 & $1-5$ & 3,7 & 0,70 & $-0,57$ & .751 \\
\hline & $\begin{array}{l}\text { Støtte fra } \\
\text { medstude- } \\
\text { rende }\end{array}$ & $\begin{array}{l}\text { "Jeg kan få hjælp og } \\
\text { støtte fra mine medstu- } \\
\text { derende, når jeg har } \\
\text { brug for det." }\end{array}$ & 3 & $1-5$ & 4,2 & 0,63 & $-0,97$ & .657 \\
\hline & $\begin{array}{l}\text { Alignment } \\
\text { i under- } \\
\text { visningen }\end{array}$ & $\begin{array}{l}\text { "Jeg er klar over, hvad } \\
\text { jeg forventes at lære i } \\
\text { fagene." }\end{array}$ & 4 & $1-5$ & 3,6 & 0,70 & $-0,73$ & .774 \\
\hline & $\begin{array}{l}\text { Vægt på } \\
\text { forståelse }\end{array}$ & $\begin{array}{l}\text { "Undervisningen hjæl- } \\
\text { per mig til at kunne } \\
\text { vurdere hvad der ligger } \\
\text { bag forskellige viden- } \\
\text { skabelige synspunkter." }\end{array}$ & 3 & $1-5$ & 3,7 & 0,76 & $-0,51$ & .719 \\
\hline & $\begin{array}{l}\text { Tiltro til } \\
\text { egne fagli- } \\
\text { ge evner }\end{array}$ & $\begin{array}{l}\text { "Jeg har tiltro til, at jeg } \\
\text { kan klare mig godt, så } \\
\text { længe jeg yder en ind- } \\
\text { sats." }\end{array}$ & 5 & $1-5$ & 4,1 & 0,64 & $-0,86$ & .830 \\
\hline \multirow[t]{3}{*}{ Baggrund } & Alder & Alder i antal år & & $18-57$ & 23,9 & 3,75 & 3,42 & \\
\hline & $\begin{array}{l}\text { Karakte- } \\
\text { rer-gns. }\end{array}$ & $\begin{array}{l}\text { Gennemsnit af de ka- } \\
\text { rakterer, som den stu- } \\
\text { derende har opnået på } \\
\text { sin bachelor/kandidat } \\
\text { indtil tidspunktet for } \\
\text { dataindsamlingen. }\end{array}$ & & $-3-12$ & 7,2 & 1,93 & $-0,88$ & \\
\hline & Køn & $\begin{array}{l}\text { Kvinde (mand er refe- } \\
\text { rencekat.) }\end{array}$ & & \multicolumn{5}{|c|}{$\begin{array}{l}0 \text { (mand) } \\
1 \text { (kvinde) }\end{array}$} \\
\hline
\end{tabular}


Studietrin

Første år (bach.)

Andet år (bach.)

Tredje år (bach.)

Fjerde år (kand.)

Femte år (kand.)

“Nogle gange kan jeg

godt tvivle på om det

var det rigtige valg at læse det her fag."
$19 \%$

$19 \%$

$23 \%$

$18 \%$

$21 \%$

0 ('helt uenig', 'overvejende uenig' eller 'hverken enig eller uenig')

1 ('overvejende enig' eller 'helt enig')

a) En refleksiv skala er en skala, hvor skalascoren er en sammenregning af scoren på en række enkeltspørgsmål (items) som antages at afspejle (reflektere) et underliggende latent fænomen, som ikke lader sig måle direkte. Cronbachs alfa ( $\alpha)$ er et mål for skalaens interne reliabilitet.

Afhængig variabel
Studietvivl 